\title{
WARIANTY MORFOLOGICZNE CZASOWNIKA BYĆ W MOWIE MIESZKAŃCÓW SPISZA NA PODSTAWIE DANYCH KORPUSOWYCH
}

Słowa klucze: morfologia, czasownik, gwara, dane korpusowe Keywords: morphology, verb, dialect, corpus data

\section{Wprowadzenie}

Czasownik być ze względu na swą nieregularność ma w polszczyźnie osobliwą odmianę, opierającą się na czterech supletywnych tematach: jest-, s-, by- oraz będ- (z alternantami: będź- i bądź-) (Laskowski 1998: 235). Być jest czasownikiem niedokonanym, ale tworzy czas przyszły prosty z podstawą będ-. Czas przeszły oparty jest na temacie by-, np. byłem, byliśmy. Ruchome końcówki występują nie tylko w czasie przeszłym (jak w innych czasownikach), ale również w czasie teraźniejszym, np. jam jest. Od XVI w. występują w czasie teraźniejszym formy osobowe tworzone na wzór czasu przeszłego. Ich podstawę tworzy temat jest, do którego dodawane są końcówki osobowe w 1. i 2. os. lp. oraz $\mathrm{lm}$., a 3. os. $\mathrm{lm}$. ma postać supletywną są (Klemensiewicz, Lehr-Spławiński, Urbańczyk 1955: 363-364; Mańczak 1975: 118-119; Pospiszylowa 1999: 56). Czasownik być występuje jako samodzielne orzeczenie w zdaniu, może ponadto pełnić funkcję gramatyczną jako składnik złożonych form czasowników oraz orzeczeń imiennych.

W odmianie gwarowej czasownik być pełni taką samą funkcję jak w polszczyźnie ogólnej, jednak napotykamy tu szereg odmienności w budowie form fleksyjnych, 
dystrybucji końcówek oraz w połączeniach $\mathrm{z}$ innymi wyrazami. Rozpowszechnionymi wariantami w gwarach są struktury analityczne typu ja był. Inne formy ograniczają się do mniejszych obszarów, np. końcówka -ch w 1. os. lp. czasu przeszłego i teraźniejszego typu byłech, jestech występuje w gwarach południowej Małopolski i Śląska oraz na Warmii i w Ostródzkiem (SGP III: 175-264; także MAGP X: m. 455, $457)^{1}$. Zenon Sobierajski zarejestrował w gwarze spiskiej warianty fleksyjne czasownika być, m.in. ja jech młody, ty jeś młody, ja bem robić (APGS IV: 48-60).

Materiały do wspomnianych opracowań słownikowych oraz atlasowych pochodzą sprzed prawie 60 lat w przypadku atlasu Z. Sobierajskiego (APGS), a dwóch pozostałych są jeszcze starsze. Język mieszkańców wsi od tego czasu przeszedł dynamiczne zmiany w kierunku upodobnienia się do języka standardowego. Zakładamy, że archaiczne formy w dużej mierze zostały wyparte przez warianty z języka ogólnego.

Celem niniejszego artykułu jest omówienie form czasownika być aktualnie używanych w mowie mieszkańców Spisza². Uwagę skupimy głównie na wariantach morfologicznych odmiennych od polszczyzny ogólnej. Materiały do analizy pochodzą z elektronicznego korpusu gwary spiskiej (Korpus Spiski). Istotnym aspektem poniższego opracowania jest wykorzystanie udogodnień, jakie daje korpus w badaniach gramatycznych kodu gwarowego. Należą do nich przede wszystkim dane o frekwencji oraz konkordancji wariantów fleksyjnych. Nowe narzędzie pozwala także połączyć wyniki ze znacznikami socjalno-demograficznymi, co szczegółowiej pokażemy na przykładzie wariantów 1. os. lp. czasu przeszłego.

\section{Materiały korpusowe - ogólna charakterystyka}

Korpus Spiski, z którego zaczerpnięto dane, jest nowym ogólnodostępnym narzędziem badawczym do przeszukiwania oraz analizy tekstów i nagrań gwarowych. Zawiera około $2 \mathrm{mln}$ form tekstowych z 250 godzin nagrań zarejestrowanych w latach 2015-2018 (Grochola-Szczepanek i in. 2019).

1 Ogólne informacje o czasownikach w gwarach polskich zebrane są w opracowaniu Dialekty i gwary polskie. Kompendium internetowe (Karaś 2010). W innych pracach autorzy ograniczają badania do mniejszych obszarów, skupiając się na wybranych zagadnieniach fleksyjnych (np. Kucała 1951; Rzetelska-Feleszko 1967; Ananiewa 1995; Pospiszylowa 1999; Cechosz 2001; Dzięgiel 2001; Grochola-Szczepanek 2019) lub słowotwórczych (np. Fadecka 2010; Czarnecka 2014).

2 W osobnym artykule omówiono osobliwości występujące w czasie przeszłym, m.in. byłech, ja byt, matka byli (Grochola-Szczepanek 2019). W niniejszym opracowaniu przywołuje się ze wspomnianego tekstu najważniejsze ustalenia dotyczące czasu przeszłego w celu przedstawienia kompletnego zestawu wariantów morfologicznych. Informacje o przywołanych formach czasu przeszłego poszerzone są o omówienie szczegółowych danych frekwencyjnych na temat wieku i płci respondentów. 
Liczba wszystkich słowoform czasownika być w Korpusie Spiskim wynosi ponad 97 tys. Należy tutaj uściślić, że w rozumieniu twórców korpusu za słowoformę uznaje się wyraz lub jego element, np. forma czasownika byłbyś zawiera słowoformy: byt, by i ś, zlematyzowane jako być, by i być. Ten ostatni element to ruchomy morfem, mogący dołączać się do innych części mowy poza czasownikiem (ibid.: 168). Forma samego bezokolicznika być występuje w korpusie prawie 1500 razy. Zbiór wynotowanych z korpusu wariantów form koniugacyjnych czasownika być typu byłem, ja byt, jech byt itp. liczy ponad 60 tys. jednostek.

Omawiając poniżej typy form koniugacyjnych, notujemy przykłady występowania w szerszym kontekście. Cytaty podajemy w zapisie standaryzowanym, jaki zastosowano w Korpusie Spiskim (ibid.: 170-173). Formy czasownikowe, w których występują zmiany morfologiczne, zaznaczamy także w wersji gwarowej, np. byłem/l bytef. Przy omawianych wariantach notujemy liczbę wystąpień w korpusie, np. byłef (170). Po każdym cytowanym fragmencie podawany jest identyfikator respondenta, np. (M4-1944-LapszeNizne) lub (K11-1968-Frydman). Identyfikatory pozwalają odczytać podstawowe metadane o informatorze: płeć: $\mathrm{M}$ - mężczyzna, $\mathrm{K}$ - kobieta, 4, 11 - numer porządkowy, 1944, 1968 - rok urodzenia, LapszeNizne, Frydman miejscowość, z której pochodzi nagranie. System identyfikatorów wykorzystuje konwencję przyjętą przez twórców korpusu: dwuczłonowe nazwy miejscowości typu Łapsze Niżne mają ciągłą pisownię, ponadto nie zawierają znaków diakrytycznych, czyli mamy zapis LapszeNizne.

Baza korpusu oparta jest na wywiadach z 340 respondentami we wszystkich 15 wsiach spiskich. Udział grup pokoleniowych respondentów jest następujący: najstarsi (powyżej 6o roku życia) - 53\%, w średnim wieku (w przedziale 40-59 lat) oraz najmłodsi (do 39 roku życia) po równo - 23,5\%. Liczba danych językowych zebranych w tych grupach wynosi: najstarsi $-65 \%$, w średnim wieku $-22 \%$, najmłodsi $-13 \%$. Pomimo wyrównanej liczby respondentów w średnim i najmłodszym wieku widoczne różnice $\mathrm{w}$ ilości danych wynikają z tego, że wywiady z najmłodszymi trwały krócej niż ze starszymi respondentami. Twórcy korpusu celowo dążyli do nadreprezentacji osób starszych,

a więc takich, wśród których gwara jest zachowana najlepiej i ma najmniej cech przejętych z języka ogólnopolskiego. Duża liczebność tej grupy zapewnia względną obfitość danych, które dają dostęp do możliwie czystego systemu gwarowego. Z drugiej strony nagrania przedstawicieli średniego i najmłodszego pokolenia pozwalają obserwować procesy utraty cech gwarowych pod wpływem języka ogólnego (ibid.: 168).

Udział męskich i żeńskich respondentów jest dosyć wyrównany i wynosi 157 mężczyzn $(46,2 \%)$ i 183 kobiety $(53,8 \%)$. 


\section{Postać aorystyczna}

Gwara spiska zachowuje w czasie przeszłym, obok wariantów znanych z języka ogólnego byłem, byłam, aorystyczne postaci byłech, byłach. Formom towarzyszy przejście wygłosowego -ch $>-f$ lub - $k$, występują zatem formy byłef, byłaf lub byłek, byłak. Poniższe zestawienia pokazują frekwencję występowania wariantów gwarowych oraz ogólnych.

Liczba wystąpień:

- formy aorystyczne: byłef (170), byłaf (147), byłek (87), byłak (61); łącznie (465),

- formy ogólne: byłem (239), byłam (122); łącznie (361).

Przykłady:

(1) Drugi raz byłem//bytef też byłem//byłef na eksporcie (M2-1941-LapszeWyzne);

(2) Tak nie byłam//byłak nie chodziłam za granicę do roboty (K2-1941-Jurgow).

Formy aorystyczne sporadycznie pojawiają się w czasie teraźniejszym: jestef, jestek, także ze zmianą $\mathrm{w}$ temacie $\mathrm{w}$ postaci udźwięcznienia: jezdem oraz uproszczenia: jezek. Warianty te stanowią nieliczne poświadczenia w odniesieniu do powszechnej formy jestem.

Liczba wystąpień:

- jestef (4), jezdef(1), jezef(1), jestek (1), jezek (1) : jestem (225); łącznie (233).

Przykłady:

(3) Od wtedy jestem//jestef tu w Eapszach (K11-1975-LapszeWyzne);

(4) Ona chyba teżpochodziz Łapszanki nie jestem/ljezefpewny(M1-2002-Kacwin).

Postać aorystyczna występuje także w trybie przypuszczającym: bytbyf (7), byłabyf (4), byłbyk (1), bałabyk (2), byf był (1), byf była (2) : byłbym (3), byłabym (1); łącznie (21).

\section{Formy analityczne}

Powszechnym zjawiskiem w odmianie gwarowej jest występowanie form opisowych typu ja byt, my są. W ten sposób wyrażana jest 1. os. lp. i lm. w czasie przeszłym oraz teraźniejszym.

Pierwsza osoba czasu przeszłego realizowana jest przy użyciu konstrukcji ja byt, ja była. Składają się na nią zaimek osobowy ja oraz formy 3. os. lp. był, była.

Liczba wystąpień:

- ja był (206), ja była (229), także z zaprzeczeniem: ja nie był (9), ja nie była (12); łącznie (456). 
Przykłady:

(5) Jak już kielo telo ja był większy no to trza było kosić (M2-1951-Falsztyn);

(6) Ja nie była $w$ kościele (K6-1944-CzarnaGora).

Forma analityczna wyrażająca 1. os. lp. czasu teraźniejszego składa się z zaimka osobowego ja oraz 3. os. lp. jest.

Liczba wystąpień:

- ja jest (90), z zaprzeczeniem ja nie jest (3); łącznie (93).

Przykłady:

(7) Ja pochodzęz Frydmana ja jest tutaj autochtonem (K5-1964-Frydman);

(8) Bo ja nie jest taka uczona (K3-1939-Lapszanka).

W 1. os. $\mathrm{lm}$. czasu przeszłego konstrukcja opisowa składa się z zaimka my oraz formy 3. os. $1 \mathrm{~m}$. byli, byty.

Liczba wystąpień:

- my byli (358), my były (112), także z zaprzeczeniem: my nie byli (7), my nie były (4); łącznie (481).

Przykłady:

(9) My byli przy Stowacji (K9-1929-NowaBiala);

(10) To tak się rodziło my nie byty $w$ szpitalach nikany $w$ domu my rodzity (K1-1928-Jurgow).

Sobierajski podczas badań na Spiszu w latach 6o. ubiegłego wieku pisał o tym, że gwara spiska nie ma właściwej formy 1. os. lm. jesteśmy, a zastępujące ją konstrukcje my są i my jest są trudne do uchwycenia u respondentów:

w niektórych wsiach spiskich nie można było usłyszeć nawet form zastępczych my sa, my jest, mimo że starałem się sprowokować informatorów do ich użycia. Słyszy się tam najczęściej jedynie my młodzi, my na dole, my w kościele (APGS IV: 50).

Dane z Korpusu Spiskiego pokazują, że konstrukcje my sa i my jest używane są aktualnie przez mieszkańców Spisza. Forma ogólna jesteśmy występuje ponad trzy razy rzadziej w stosunku do form analitycznych.

Liczba wystąpień:

- my sa (130), my jest (2) : jesteśmy (41); łącznie (173).

Przykłady:

(11) Pomimo tego że sa sasiednie regiony to to jednak my sa catkiem inni (M5-1987-Krempachy);

(12) My jest Polakami (M10-1941-Kacwin). 


\section{Ruchoma końcówka}

Zjawisko ruchomej końcówki, czyli dołączania końcówek osobowych czasowników do innych części mowy, np. już.em był, zwane także aglutynantem (NKJP), związane jest z rozwojem dawnego czasu przeszłego złożonego. Czas ten składał się z imiesłowu przeszłego czynnego i słowa posiłkowego być, np. był jeśm, był jeś itp. W wyniku wielowiekowego procesu uproszczenia jeśm, jeś stały się końcówkami -em, -eś, które połączyły się z imiesłowem, tworząc znane obecnie formy byłem, byłeś. W ruchomej końcówce czasowników można dopatrywać się resztek czasu złożonego. W gwarach zjawisko to występuje o wiele częściej niż w języku ogólnym. W całej bazie Korpusu Spiskiego odnotowano ponad 5500 przykładów dołączenia końcówek gwarowych do różnych części mowy w samej tylko 1 os. lp. Najczęściej końcówki czasowników dołączane są do wyrazów: jak, już, tak, potem, te $\dot{z}$, raz, tam, teraz, że.

Aglutynanty czasownika być obejmują prawie 770 przypadków, z czego zdecydowana większość przypada na 1. os. lp. czasu przeszłego. Ruchoma końcówka najczęściej łączy się ze spójnikiem jak (60), np. jak.em/ljak.ef był, jak.em/ljak.ek była. Wyrazy zakończone na samogłoskę łączą się z końcówkami $-f,-k,-m$, natomiast zakończone na spółgłoskę - z końcówkami -ef, -ek, -em.

Liczba wystąpień:

- typ z końcówką gwarową: .f był (44), .f była (93), .k był (23), .k była (41); łącznie (201),

- .ef byt (38), .ef była (67), .ek był (21), .ek była (11); łącznie (137),

- typ z końcówka ogólną: .m był (3), .m była (2), .em był (2); łącznie (7).

Przykłady:

(13) Już wieksza.m//wiynkso.k była (K3-1939-Lapszanka);

(14) Jak.em//jak.ef była indyki skubać parę piórek wzięła (K3-1939-Frydman);

(15) Pierwszy raz.em//roz.em był na wywiadówce (M11-1952-Trybsz).

Niewiele wyników z ruchomą końcówką znajdujemy dla 1. os. lp. czasu teraźniejszego typu: ja.m jest, taki.m jest, która przybiera postać z wygłosowym -ch realizowanym jako $-f$ lub $-k(13)$.

Przykłady:

(16) Bywam na Spiszu no to.m//to.f jest Spiszka nie? (K5-1950-Niedzica);

(17) Nie mogę powiedzieć że.m//ze.k jest w stu procentach narodowości słowackiej (K-1987-Jurgow).

Ruchoma końcówka występuje także w 2. os. lp. i lm. czasu teraźniejszego i przeszłego, np. jak.eś byt, wy.ście sa, w domu.ś jest. Najczęściej końcówka łączy się z zaimkami osobowymi ty: ty.ś jest, ty.ś był (21) oraz wy: wy.ście sa, wy.ście jest, wy.ście byli, wy.ście były, wy.ście był (6). 
Liczba wystąpień:

- .ś jest (36), . eś jest (1) : jesteś (22); łącznie (59),

- .ście są (11), .ście jest (1) : jesteście (6); łącznie (18),

- .ś był (55), .ś była (18), .eś był (2), .eś była (4) : byłeś (20), byłaś (16); łącznie (115),

- .ście byli (43), .ście były (4), .ście był (3) : byliście (26), byłyście (8); łącznie (84). Przykłady:

(18) Przecież jak.eś jest z Niedzicy (M7-1947-CzarnaGora);

(19) Ty.ś jest skąd? (M8-1926-Niedzica);

(20) Wy.ście są za mądrzy na wojsko (M4-1957-Frydman);

(21) Wy.ście jest bracie niepilok (K-1971-Łapszanka);

(22) Tak było a dziś nam gadaja bo.ście był głupi (M3-1939-LapszeWyzne).

\subsection{Aglutynant wolnostojący}

Ruchoma końcówka czasownika w gwarze nie tylko łączy się z innymi wyrazami, lecz pozostaje także wolnostojąca, np. już em byt. Dowodem na to jest sposób wymawiania: wyraźne wydzielenie końcówki oraz intonacja. Wolnostojący aglutynant zachowuje uproszczoną formę słowa posiłkowego jeśm, z aorystyczną postacią jech, która w gwarze wymawiana jest jako: jef, jek.

Liczba wystąpień:

- jef był (18), jef była (38), jek był (13), jek była (12), efbyła (2), ek był (1), był jef (1), była jef (2), była jek (1); łącznie (88).

Przykłady:

(23) Czterdzieści roków em/ljef byt lektorem $w$ kościele i kantorem zarazem (M6-1954-Dursztyn);

(24) Była em//jek w Rzymie długo (K4-1943-CzarnaGora);

(25) Dopiero za granica em//ef była teraz jak już syn wyjechał do Ameryki (K18-1934-Niedzica).

\subsection{Aglutynant z partykułą że-}

Pod wpływem polszczyzny potocznej upowszechniają się formy wzmocnione partykułą że- typu ja żem byt. W gwarze realizowane są zwykle z końcówką aorystyczną: zef, zek i dotyczą w większości przykładów w czasie przeszłym.

Liczba wystąpień:

- zef był (7), zef była (21), zek był (3), zek była (1), była zef (2), żem był (2), żem była (2), żem jest (2), zef jest (5), zek jest (1); łącznie (46). 
Przykłady:

(26) Jak żem//zek byt maly no to mama mi kupiła taka siatkę (M13-2006-Trybsz);

(27) Potem żem//zef była $w$ Krakowie (K7-1978-Falsztyn);

(28) Nie byłem mocarzem bo żem//zef jest małego wzrostu (M1-1980-Dursztyn);

(29) Z mojego rocznika to żem//zek jest tu jedyna dziewczyna na wsi (K4-1997-Lapszanka).

Tabela 1. Zestawienie form czasownika być w czasie przeszłym

\begin{tabular}{|c|c|c|}
\hline Czas przeszly & Liczba pojedyncza & Liczba mnoga \\
\hline 1. os. & $\begin{array}{l}\text { byłef, byłaf, byłek, byłak (459) } \\
\text { ja byt, ja była }(456) \\
\text { byłem, byłam }(361) \\
\text { fbyt, f była, .k byt, .k była, .ef byt, ef była, } \\
\text { ek byt, .ek była, .m byt, .m była, .em byt (338) } \\
\text { jef byt, jef była, jek byt, jek była, ef była, } \\
\text { ek byt, byt jef, była jef, była jek (88) } \\
\text { zef byt, zef była, zek byt, zek była, żem byt, } \\
\dot{z} e m \text { była (40) } \\
\dot{z} e m \text { byt, żem była (4) }\end{array}$ & $\begin{array}{l}\text { my byli, my byly ( } 481) \\
\text { bylimy, bylymy (141) } \\
\text { byliśmy, bylyśmy (18) }\end{array}$ \\
\hline 2. os. & $\begin{array}{l}\text { byłeś, byłaś (91) } \\
\text { ś byt, ś była (73) }\end{array}$ & $\begin{array}{l}. \text { ście byli, ś́cie byly, ś́cie był (50) } \\
\text { byliście, bytyście ( } 28)\end{array}$ \\
\hline 3. os. & byl, była (27 090) & byli, byty (11 306) \\
\hline
\end{tabular}

\section{Byliśmy : bylimy}

W 1. os. lm. spotyka się zazwyczaj warianty z końcówką -my, np. bylimy, bylymy. Znacznie rzadziej spotykamy ogólnopolskie formy byliśmy, byłyśmy, które używane są głównie przez młodszych mówców.

Liczba wystąpień:

- bylimy (109), bylymy (32); łącznie (141);

- byliśmy (17), bytyśmy (1); łącznie (18).

Przykłady:

(30) Byliśmy//bylimy w tym spółku Świętego Wojciecha w Trnavie (K6-1927-Trybsz);

(31) Bytyśmy//bytymy na Wegrzech z tym występem (K18-1934-Niedzica). 


\section{On jest :je: jest je}

W 3. os. lp. czasu teraźniejszego występuje powszechnie forma jest (14 950), zwykle pozbawiona w wymowie końcowej spółgłoski - $t$ (jes). Starsi mieszkańcy używają skróconego wariantu je (255).

Przykłady:

(32) Bo jak jest/lje w robocie (K18-1934-Niedzica);

(33) Piosneczka jest//je piękna (M8-1924-LapszeWyzne).

W 3. os. lp. występuje charakterystyczna dla osób starszych podwojona konstrukcja jest je (11). Najwięcej poświadczeń tego wariantu pochodzi od mówców z miejscowości Rzepiska.

Przykład:

(34) Ten mu nie chce dać i jest jest//je markotny na niego (K10-1932-Rzepiska).

\section{Oni sq: onijest}

W 3. os. lm. mamy formę znaną z polszczyzny ogólnej oni sq (65). W jednym przypadku wystąpiła konstrukcja oni jest:

(35) I oni jest naród taki taki po prostu zacięty (K-1955-Dursztyn).

Tabela 2. Zestawienie form czasownika być w czasie teraźniejszym

\begin{tabular}{|c|c|c|}
\hline Czas teraźniejszy & Liczba pojedyncza & Liczba mnoga \\
\hline 1. os. & $\begin{array}{l}\text { jestem }(225) \\
\text { ja jest }(93) \\
\text { f jest, .k jest, .m jest (13) } \\
\text { zef jest, zek jest, żem jest (10) } \\
\text { jestef, jezef, jestek, jezek (8) }\end{array}$ & $\begin{array}{l}\text { jesteśmy (173) } \\
\text { my sq (130) } \\
\text { my jest (2) }\end{array}$ \\
\hline 2. os. & $\begin{array}{l}. s ́ \text { jest, .eś jest (59) } \\
\text { jesteś (22) } \\
\dot{z} \text { eś jest }(4)\end{array}$ & $\begin{array}{l}\text { jesteście (7) } \\
\text { wy.ście sq, wy.ście jest (7) }\end{array}$ \\
\hline 3. os. & $\begin{array}{l}\text { jest }(14950) \\
\text { je }(255) \\
\text { jest je (11) }\end{array}$ & $\begin{array}{l}\text { oni sq }(65) \\
\text { oni jest (1) }\end{array}$ \\
\hline
\end{tabular}




\section{Skrócenia tematu w czasie przyszłym}

Formy koniugacyjne czasownika być w czasie przyszłym oparte są na temacie bed(z alternantami bedz- i bydź-, by-), np. bedym 'będę', bedzie 'będzie', bydź 'bądź', bycie 'bądźcie'. Występują zwykle w kilku wariantach oraz podlegają skróceniu tematu, np. bedym > bem, bedzies $>$ bes, będzie $>$ be. Formy skrócone występują we wszystkich osobach liczby pojedynczej oraz w 1. i 2. os. $1 \mathrm{~m}$. Dane liczbowe w korpusie wskazują, że formy skrócone są częściej stosowane niż pozostałe warianty. Szczególnie widać to na przykładzie form 1. os. $1 \mathrm{~m}$. zakończonych na -me, w których wariant skrócony beme występuje trzykrotnie częściej niż wariant bedyme (tabela 3). Formy skrócone występują zarówno u starszych, jak i młodszych respondentów we wszystkich miejscowościach spiskich.

Tabela 3. Zestawienie form czasownika być w czasie przyszłym

\begin{tabular}{lll} 
Czas przyszły & \multicolumn{1}{c}{ Liczba pojedyncza } & \multicolumn{1}{c}{ Liczba mnoga } \\
\hline & bem $(263)$ & beme $(122)$ \\
bedyme $(186)$ & bedymy (28) \\
1. os. & bede $(45)$ & bedziemy, bedziymy (16) \\
& będę, będe (17) & bemy (12) \\
& bes (168) & becie (60) \\
2. os. & bedzies (131) & bedziecie (45) \\
& bedzie, będzie (1250) & bedą (442) \\
3. os. & be (395) &
\end{tabular}

Przykłady:

(36) W chałupie nie będziesz//bes siedział bo co w tej chałupie będziesz//bes robit? (K4-1997-Łapszanka);

(37) Tu stół mamy duży tu będziemy//beme siedzieć (K4-1955-Dursztyn).

\section{Będę: bedym}

W 1. os. lp. czasu przyszłego na całym Spiszu dominuje końcówka -ym. Jest ona powszechna także dla czasu teraźniejszego. Jak wspomnieliśmy powyżej, forma bedym (186) zwykle skracana jest do bem (263). Niektórzy respondenci używają wariantu bede (45), który jest charakterystyczny dla gwary podhalańskiej.

Przykłady:

(38) Gadać nie będę//bedym po rusku (K14-1941-Niedzica);

(39) Nie będę//bede opowiadał bo to nie jest temat do opowiadania (M6-1966-Frydman). 
Analizując szczegółowiej występowanie podhalańskiego wariantu bede, zauważono, że ponad połowa poświadczeń pochodzi od respondentów z Czarnej Góry, sąsiadującej bezpośrednio $\mathrm{z}$ Podhalem. Pozostałe przypadki formy bede zarejestrowano u respondentów z kilku innych wsi. Są to osoby pochodzące z Podhala lub mające bliskich członków rodziny z tego regionu.

\section{Bedyme: bedymy}

Pierwsza osoba $\mathrm{lm}$. czasu przyszłego opiera się na formie 1. os. lp. bedym - bedyme, bedymy, w przeciwieństwie do języka ogólnego: będę-będziemy. Formy zakończone są dwiema końcówkami: - me lub -my. Przewagę liczebną mają warianty zakończone na -me (160), przy czym w większości są skrócone do formy beme (122). Cztery razy rzadziej występują formy z -my: bedymy (28) i bemy (12).

Przykłady:

(40) Będziemy//bedyme żyćdopóki nam Pan Bógpozwoli razem(M4-1957-Frydman);

(41) No to na litry to już nie będziemy//beme liczyć (M2-1950-Rzepiska);

(42) Będziemy//bedymy nowe stawiać bo tu niefajnie na oborze (K2-1972-Kacwin).

Występowanie końcówek -me i -my ma określony zasięg geograficzny. Typ bedyme, beme występuje prawie na całym terenie, wyjątek stanowią dwie wioski: Kacwin i Jurgów, w których dominuje typ bedymy, bemy.

\section{Wariant morfologiczny a metadane}

Wśród form czasownika być największe zróżnicowanie wykazuje 1. os. lp. czasu przeszłego. Występuje tutaj 7 typów wariantów morfologicznych o łącznej liczbie 1746 form. Najliczniej reprezentowane są formy aorystyczne byłech (459) oraz analityczne ja był (456). Nieco mniej poświadczeń ma typ byłem (361) oraz formy z ruchomą końcówką typu jak.ech był (338). Najrzadziej występują formy z wolnostojącym aglutynantem typu jech był (88) oraz wzmocnione partykułą typu żem był (44) (por. tabela 1). Przy tak dużym zróżnicowaniu powstaje pytanie o wpływ parametrów socjolingwistycznych (np. wiek i płeć) oraz geograficznych na występowanie wariantów.

Analiza czynnika wieku pozwala zaobserwować charakterystyczne tendencje $\mathrm{w}$ grupach wiekowych ${ }^{3}$. Jedną z nich jest zanikanie wariantów analitycznych typu ja

3 Dane dotyczące wpływu wieku na język podaje się na podstawie analizy danych frekwencyjnych wyrazów w korpusie. W związku z tym, że poszczególne grupy wiekowe są nierównomiernie 
był. U najstarszych respondentów (60+) formy opisowe są dominującymi wariantami (ok. 32\%). Respondenci z pokolenia średniego (40-59 lat) częściej używają form ogólnych bytem (prawie 32\%) i aorystycznych byłech (ponad 24\%) niż opisowych ja był (ponad 20\%). W grupie najmłodszych rozmówców (poniżej 39 roku życia) liczba form analitycznych ja był wynosi tylko $8 \%$. Podobna tendencja dotyczy form $\mathrm{z}$ aglutynantem typu tam.ech był i jech był. Ruchoma końcówka przyłączona do innych wyrazów pojawia się czterokrotnie rzadziej u młodych informatorów (ok. 6\%) niż u starszych mówców (24\%). Wolno stojące aglutynanty typu jech był nie występują w ogóle u najmłodszych, w zamian za to pojawia się leksem stosowany w potocznym języku ogólnym: żem był, który przybiera także postać żech był. U młodszych mieszkańców występuje wyraźna tendencja do używania form typu byłech (prawie 47\%) oraz byłem (ponad 32\%) (tabela 4).

Tabela 4. Warianty dla 1. os. lp. czasu przeszłego z uwzględnieniem czynnika wieku liczba wystąpień w przeliczeniu na \%

\begin{tabular}{|c|c|c|c|c|}
\hline Typ wariantu & Młodzi & $\begin{array}{l}\text { W średnim } \\
\text { wieku }\end{array}$ & Starzy & Razem \\
\hline $\begin{array}{l}\text { formy aorystyczne } \\
\text { (byłech, byłach) }\end{array}$ & $115(46,75 \%)$ & $97(24,56 \%)$ & $247(22,35 \%)$ & $459(26,29 \%)$ \\
\hline formy ogólne (byłem, byłam) & $80(32,52 \%)$ & $126(31,90 \%)$ & $155(14,03 \%)$ & $361(20,68 \%)$ \\
\hline $\begin{array}{l}\text { formy analityczne } \\
(j a b y t, j a b y t a)\end{array}$ & $20(8,13 \%)$ & $81(20,51 \%)$ & $355(32,13 \%)$ & $456(26,12 \%)$ \\
\hline $\begin{array}{l}\text { formy z ruchomą końcówką } \\
\text { (jak.ech był, w sklepie.ch była) }\end{array}$ & $15(6,10 \%)$ & $54(13,67 \%)$ & $269(24,34 \%)$ & $338(19,36 \%)$ \\
\hline $\begin{array}{l}\text { aglutynant wolnostojący } \\
(\text { jech był, jech była) }\end{array}$ & $0(0,00 \%)$ & $15(3,80 \%)$ & $73(6,61 \%)$ & $88(5,04 \%)$ \\
\hline $\begin{array}{l}\text { z partykułą że- } \\
\text { (̇ech był, żech była) }\end{array}$ & $13(5,28 \%)$ & $21(5,32 \%)$ & $6(0,54 \%)$ & $40(2,29 \%)$ \\
\hline $\begin{array}{l}\text { z partykułą że- } \\
(\dot{z} e m \text { byl, żem była) }\end{array}$ & $3(1,22 \%)$ & $1(0,25 \%)$ & $0(0,00 \%)$ & $4(0,23 \%)$ \\
\hline łączna liczba wystąpień & $246(14,09 \%)$ & $395(22,62 \%)$ & $1105(63,29 \%)$ & $1746(100 \%)$ \\
\hline
\end{tabular}

Z analizy zależności wariantów od płci wynika, że u męskich respondentów najczęściej występują formy typu byłech (prawie $29 \%$ ) oraz byłem (ponad 27\%). W wypowiedziach kobiet najwięcej jest form analitycznych typu ja była (prawie 28\%) oraz $\mathrm{z}$ ruchomą końcówką typu tam.ech była (prawie 25\%). Wyniki w tabeli 5 pozwalają

reprezentowane w korpusie (zob. pkt. 2), używamy frekwencji względnych: częstość wariantu $\mathrm{w}$ danej grupie dzielona jest przez liczbę wszystkich wyrazów w tej grupie. Otrzymane w ten sposób dane reprezentują, z jaką częstotliwością dany wyraz używany jest w odpowiedniej grupie wiekowej. 
zaobserwować zatem dwie przeciwne tendencje: $z$ jednej strony dążenie do form syntetycznych u mężczyzn, a z drugiej - przewagę wariantów analitycznych u kobiet.

Tabela 5. Warianty dla 1. os. lp. czasu przeszłego z uwzględnieniem czynnika płci - liczba wystąpień w przeliczeniu na \%

\begin{tabular}{|c|c|c|c|}
\hline Typ wariantu & Mężczyźni & Kobiety & Razem \\
\hline formy aorystyczne (bytech, byłach) & $254(28,80 \%)$ & $205(23,70 \%)$ & $459(26,29 \%)$ \\
\hline formy ogólne (byłem, byłam) & $239(27,10 \%)$ & $122(14,10 \%)$ & $361(20,68 \%)$ \\
\hline formy analityczne (ja byt, ja była) & $215(24,38 \%)$ & $241(27,86 \%)$ & $456(26,12 \%)$ \\
\hline $\begin{array}{l}\text { formy z ruchomą końcówką } \\
\text { (jak.ech byt, w sklepie.ch była) }\end{array}$ & $126(14,29 \%)$ & $212(24,51 \%)$ & $338(19,36 \%)$ \\
\hline $\begin{array}{l}\text { aglutynant wolnostojący } \\
\text { (jech byt, jech była) }\end{array}$ & $33(3,74 \%)$ & $55(6,36 \%)$ & $88(5,04 \%)$ \\
\hline z partykułą że- (żech byt, żech była) & $14(1,59 \%)$ & $26(3,01 \%)$ & $40(2,29 \%)$ \\
\hline z partykułą że- (்̇m byt, żem była) & $3(0,34 \%)$ & $1(0,12 \%)$ & $4(0,23 \%)$ \\
\hline łączna liczba wystąpień & $882(50,51 \%)$ & $865(49,54 \%)$ & $1746(100 \%)$ \\
\hline
\end{tabular}

Zasięg form aorystycznych byłef lub byłek ma wyraźny związek z realizacją wygłosowego - ch. Typową cechą spiską jest przejście -ch w -f (na tyf staryf nogaf). Taka wymowa obejmuje prawie cały Spisz, z wyjątkiem trzech wsi: Czarna Góra, Jurgów i Rzepiska, w których wygłosowe -ch realizowane jest jako -k (na tyk staryk nogak). Jest to cecha charakterystyczna dla Podhala sąsiadującego ze Spiszem. Z danych w korpusie wynika, że formy byłek, byłak występują także poza tymi trzema wsiami. $\mathrm{Na} 148$ wyników z zakończeniem - $k 27$ form występuje we wsiach, w których tradycyjnie przyjmuje się wymowę wygłosowego -ch jako - $f$ (Małecki 1928; APGS). Rodzi się zatem pytanie o przyczynę występowania realizacji typu byłek, byłak we wsiach, w których spodziewalibyśmy się form byłef, byłaf. Pomoc znajdujemy w szczegółowych metadanych, z których wynika, że obecność cechy poza schematycznie przyjętą granicą ma tu związek głównie $z$ pochodzeniem respondenta lub jego rodziny $z$ innej wsi, w której jest realizacja -ch jako - $k$. Istotny wpływ może mieć także praca w środowisku, w którym dominuje taka wymowa (chodzi o Podhale) oraz wartościowanie takiej realizacji jako bardziej prestiżowej. 


\section{Podsumowanie}

Analiza wariantów morfologicznych czasownika być z Korpusu Spiskiego skłania do kilku ogólnych refleksji:

1. Wstępne założenie o wyparciu archaicznych form przez warianty ogólne nie znalazło potwierdzenia. Warianty morfologiczne, które Sobierajski zarejestrował w latach 6o. XX w., nadal występują w mowie mieszkańców Spisza. Co więcej, dane z korpusu ujawniają występowanie zjawisk, których nie uchwycono we wcześniejszych badaniach, np. analityczna forma 1. os. lm. czasu teraźniejszego my sa, my jest oraz podwojona forma 3. os. lp. czasu teraźniejszego on jest je. Duża frekwencja wariantów odmiennych od polszczyzny wskazuje, że są to struktury mocno zakorzenione w mowie mieszkańców wsi spiskich.

2. Zróżnicowanie kolekcji form fleksyjnych zależne jest od takich parametrów, jak wiek, płeć oraz zróżnicowanie geograficzne. Zauważono, że formy opisowe oraz ruchome końcówki charakterystyczne są dla starszych mówców. Im młodsza generacja respondentów, tym mniejsza liczba wariantów analitycznych oraz ruchomych końcówek. W wypowiedziach tych respondentów dominują formy syntetyczne i skąpa liczba aglutynantów. Biorąc pod uwagę czynnik płci, zauważa się, że przeważająca liczba form syntetycznych pochodzi od mężczyzn, w przeciwieństwie do kobiet, u których przeważają formy opisowe oraz aglutynanty. Filtr geograficzny wskazuje zasięgi występowania różnych typów form w poszczególnych wsiach. Jednym z zaobserwowanych zjawisk jest rozprzestrzenianie się form $\mathrm{z}$ wygłosowym $-k$ na obszarze tradycyjnej realizacji $\mathrm{z}-f$.

3. Korpus pozwala na uzyskanie dokładniejszych danych niż tradycyjny słownik lub atlas. Rezultaty wyszukiwania są policzone, opatrzone metadanymi, zawierają poszerzony kontekst oraz połączenie z nagraniem. Nie wykorzystaliśmy tutaj wszystkich możliwości danych korpusowych, np. szczegółowych powiązań ze wszystkimi metadanymi oraz badania połączeń form czasownika $\mathrm{z}$ innymi wyrazami. Omówienie zależności form czasownika od pozostałych metadanych, a także zagadnień składni czasownika być to tematy na osobne opracowania. Uważamy, że korzystnie byłoby także rozszerzyć badania nad fleksją pozostałych czasowników w Korpusie Spiskim.

\section{Literatura}

Ananiewa N., 1995, Fleksja czasownika w gwarze wsi Maćkowce i Szaróweczka na Podolu, „Studia nad Polszczyzną Kresową”, t. 8, s. 51-61.

APGS: Z. Sobierajski, Atlas polskich gwar spiskich na terenie Polski i Czechosłowacji, t. I-IV, Warszawa 1966-1977.

Cechosz I., 2001, Polska gwara Oleszkowiec na Podolu. Fleksja imienna i werbalna, Kraków. CzArneCKA K., 2014, Słowotwórstwo gwar polskich na Ukrainie. Czasownik, Kraków. 
DZIĘGIEl E., 2001, Polska gwara wsi Zielonej na Podolu na tle innych gwar południowokresowych. Fleksja imienna $i$ werbalna, Kraków.

FADECKA A., 2010, Słowotwórstwo czasownika w gwarze, Łódź.

Grochola-SzczePANeK H., 2019, Osobliwości czasu przeszłego gwarowego czasownika być na podstawie danych korpusowych, „Jezikoslovni zapiski” 25, nr 2, s. 131-142, [on-line:] https://doi.org/10.3986/JZ.25.2.8.

Grochola-SzczepaneK H., Górski R.L., von WAldenfels R., WoźniaK M., 2019, Korpus języka mówionego mieszkańców Spisza, „LingVaria” nr 1 (27), s. 165-180, [on-line:] https:// doi.org/10.12797/LV.14.2019.27.11.

Karaś H. (red.), 2010, Dialekty i gwary polskie. Kompendium internetowe, [on-line:] http:// www.dialektologia.uw.edu.pl/index.php.

Klemensiewicz Z., Lehr-Sp£awiński T., UrbańCZyk S., 1955, Gramatyka historyczna języka polskiego, Warszawa.

Korpus Spiski: H. Grochola-Szczepanek, R.L. Górski, R. von Waldenfels, M. Woźniak, Język mieszkańców Spisza. Korpus tekstów i nagrań gwarowych, [on-line:] https://www. spisz.ijp.pan.pl.

KucAŁa M., 1951, Wzmacnianie ruchomej końcówki czasu przeszłego (wtedymem poszedł, kupiłagek soli), „Język Polski” XXXI, s. 125-127.

Laskowski R., 1998, Czasownik, [w:] R. Grzegorczykowa, R. Laskowski, H. Wróbel (red.), Gramatyka współczesnego języka polskiego. Morfologia, wyd. 2 zm., Warszawa, s. 225-269.

MAGP: Mały atlas gwar polskich, oprac. Pracownia Dialektologiczna (od t. IV Pracownia Atlasu i Słownika Gwar Polskich) Zakładu Językoznawstwa PAN w Krakowie, t. I-II pod kierunkiem K. Nitscha, t. III-XIII pod kierunkiem M. Karasia, Wrocław - Kraków 1957-1970.

MAŁеCKI M., 1928, Spiskie -ch, [w:] Symbolae grammaticae in honorem Ioannis Rozwadow$s k i$, t. 2, Cracoviae, s. 443-449.

MańCZAK W., 1975, Polska fonetyka i morfologia historyczna, wyd. 2, Warszawa.

Narodowy Korpus Języka Polskiego, praca zbiorowa, red. A. Przepiórkowski, M. Bańko, R.L. Górski, B. Lewandowska-Tomaszczyk, Warszawa 2012.

NKJP: Narodowy Korpus Języka Polskiego, [on-line:] nkjp.pl.

Pospiszylowa A., 1999, Osobliwości w odmianie czasownika być w gwarze istebniańskiej, „Slavia Occidentalis” 56, s. 77-82.

Rzetelska-Feleszko E., 1967, Z problematyki czasowników zwrotnych, „Studia z Filologii Polskiej i Słowiańskiej” VII, s. 157-167.

SGP: Słownik gwar polskich, red. M. Karaś (Źródła, t. 1), J. Reichan (t. 2-9, z. 2), S. Urbańczyk (t. 2-5), J. Okoniowa (t. 6-9, z. 2), B. Grabka (t. 7-9, z. 2), R. Kucharzyk (t. 9, z. 2-t. 10, z. 2), t. 1-3: Wrocław - Warszawa - Kraków 1977-1991, t. 4-10: Kraków 1992-2019. 


\section{Morphological Variants of the Verb być 'to be' in the Speech of the Inhabitants of Spisz. Based on Corpus Data Summary}

The article discusses the morphological differences in the verb być 'to be' in the Spisz dialect. The material has been excerpted from the Spisz Dialect Corpus.

The author presents the characteristic forms, and extracts from them the different types of inflection, while providing the number of occurrences of all of the forms in the corpus. Selected examples are presented in a broader context together with metadata. The author also presents the possibilities opened by the use of an electronic corpus in morphological and sociolinguistic research.

Verbal inflection in the Spisz dialect differs from the standard variety of Polish. Archaic forms such as byłech, jestech are still used in the dialect. Analytic variants such as ja byt, my sq are restricted to older respondents. Compositions such as $w$ sklepie. $m$ by lub ja jech był are also characteristic for the older generation. Short variants like bem, bes are used in the future tense. The occurrence of the ending - $m e$ or - $m y$ in the first person plural is geographically limited. 